\title{
Obligasi Daerah Dalam Kerangka Hukum Keuangan Negara
}

\author{
Desak Putu Dewi Kasih', Ni Putu Purwanti² \\ ${ }^{1}$ Fakultas Hukum Universitas Udayana, E-mail: dewi_kasih@unud.ac.id \\ ${ }^{2}$ Fakultas Hukum Universitas Udayana, E-mail: putu_purwanti@unud.ac.id
}

\begin{tabular}{l}
\hline Info Artikel \\
Keywords : \\
Municipal Bonds; \\
State finances; \\
Investor \\
\\
\\
Corresponding Author: \\
Desak Putu Dewi Kasih, E- \\
mail: dewi_kasih@unud.ac.id \\
DOI: \\
Keuangan Negara; \\
Onvestor; \\
\\
Kanci: \\
\hline
\end{tabular}

\begin{abstract}
Bonds are long-term debt securities issued by companies or governments with a nominal value and a certain maturity period and are a type of long-term investment for investors, but for the government as the issuer of bonds is a debt that must be returned. The obligation to return the said debt creates uncertainty for investors if it considers the provisions of Article 49 Paragraph (4) of Law Number 1 of 2004 concerning State Treasury which stipulates that state / regional property is prohibited from being handed over to other parties as payment for bills to the central government /area. The purpose of this paper is to analyze and harmonize the provisions governing Municipal Bonds to achieve legal certainty. The discussion of this article uses a type of normative research, given the inconsistencies in the regulation of the issuance of municipal bonds which creates legal uncertainty in the community. The results obtained include the construction of regulation of regional bonds within the regional financial framework, both internally and externally. Furthermore, the regulation can provide legal protection to investors with a regulation that confirms the obligation of regional governments to settle obligations towards regional bond investors. Thus it can be concluded, the Normative Construction of regulation of regional bonds consists of general laws and regulations that are specific in nature, general arrangements are constructed as provisions that provide the basis for the legality of regulating regional bonds and the norms for regulating special regional bonds containing the technical requirements for issuing bonds in the form of provisions concerning requirements and procedures and legal protection for regional bond investors, law enforcement can be applied in the case of claims for compensation and the government's obligation to repay bonds issued, special provisions governing bonds.

Abstrak
Obligasi di satu sisi bagi investor merupakan investasi
jangka panjang. Di lain sisi, bagi pemerintah sebagai
penerbit obligasi merupakan hutang yang wajib
dikembalikan. Kewajiban untuk mengembalikan utang
dimaksud menimbulkan ketidakpastian bagi investor jika
memperhatikan ketentuan Pasal 49 Ayat (4) Undang-
Undang Nomor 1 Tahun 2004 tentang Perbendaharaan
Negara yang menentukan bahwa, barang milik
negara/daerah dilarang untuk diserahkan kepada pihak lain
sebagai pembayaran atas tagihan kepada pemerintah
\end{abstract}




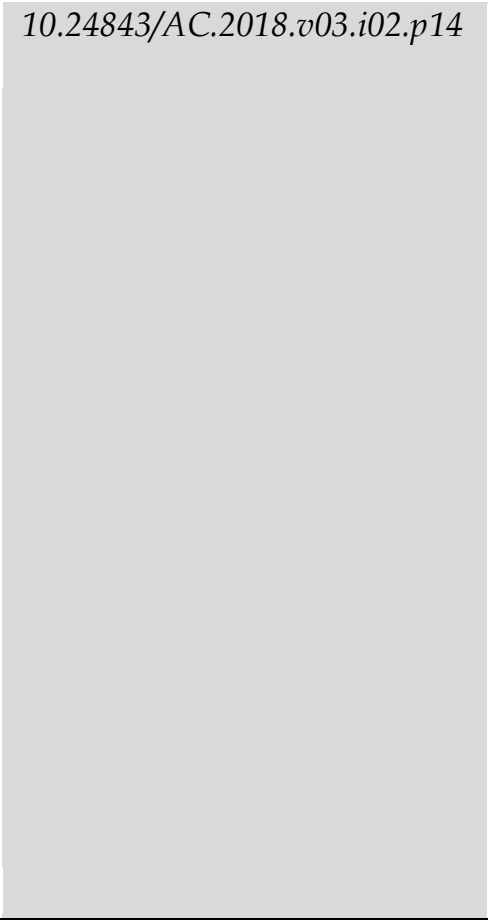

pusat/daerah. Tujuan penulisan ini untuk menganalisis dan mengharmonisasikan ketentuan yang mengatur tentang Obligasi Daerah untuk tercapainya kepastian hukum. Tulisan ini menggunakan jenis penelitian normatif, karena adanya inkonsistensi pengaturan penerbitan obligasi daerah yang menimbulkan adanya ketidakpastian hukum di masyarakat. Hasil studi menunjukkan bahwa Konstruksi Normatif pengaturan obligasi daerah terdiri dari peraturan perundang-undangan yang bersifat umum dan pengaturan yang bersifat khusus, pengaturan umum dikonstruksikan sebagai ketentuan-ketentuan yang memberikan dasar legalitas penertiban obligasi daerah dan norma pengaturan obligasi daerah yang bersifat khusus yang berisikan kaedahkaedah teknis penerbitan obligasi berupa ketentuan mengenai persyaratan dan prosedur dan perlindungan hukum terhadap investor obligasi daerah, penegakan hukumnya dapat diterapkan dalam hal tuntutan ganti kerugian dan kewajiban pemerintah untuk membayar kembali obligasi yang diterbitkan dapat dipergunakan ketentua-ketentuan khusus yang mengatur tentang obligasi.

\section{Pendahuluan}

Sumber-sumber pendanaan pelaksanaan Pemerintah Daerah secara normatif terdiri atas Pendapatan Asli Daerah (PAD) dan Perimbangan, Pinjaman Daerah dan lain-lain pendapatan yang sah. Demi tercapainya pelaksanaan atas otonomi daerah dari pemerintah daerah sangat diperlukan berbagai terobosan yang dilakukan guna memenuhi keterbatasan anggaran. ${ }^{1}$ Dalam rangka pemenuhan kebutuhan keuangan, berbagai langkah dapat dilakukan seperti bersumber dari pajak daerah, pinjaman pihak ketiga, maupun pasar uang. Lebih jauh, berdasarkan penjelasan umum Undang-undang No. 32 Tahun 2004 tentang Pemerintahan Daerah, yang disempurnakan dengan Undang-undang No. 12 Tahun 2008 ditegaskan kembali dalam Pasal 169 ayat (1), bahwa: a. Untuk membiayai penyelenggaraan pemerintah daerah, pemerintah daerah dapat melakukan pinjaman yang bersumber dari pemerintah, pemerintah daerah lain, lembaga keuangan bank, lembaga keuangan bukan bank dan masyarakat, b. Pemerintah daerah dengan persetujuan DPRD dapat menerbitkan obligasi daerah untuk membiayai investasi yang menghasilkan penerimaan daerah. Atas dasar ketentuan tersebut pemerintah daerah disamping melakukan kerjasama kemitraan dalam memperoleh sumber-sumber pembiayaan dapat pula melakukan pinjaman dan menerbitkan obligasi daerah.

Semenjak diluncurkannya produk reksadana dari Danareksa Investment Manajemen tahun 1997, disusul kemudian dengan bermunculannya berbagai macam produk instrumen pasar modal Indonesia, termasuk juga instrumen pasar modal syariah. ${ }^{2}$ Berbagai macam surat berharga seperti saham, obligasi, pasar uang atau campuran

\footnotetext{
${ }^{1}$ Okta, D., Kluge, D., 2011, Analisis Peluang Penerbitan Obligasi Daerah Sebagai Alternatif Pembiayaan Daerah, Journal of Indonesian Applied Economics, 5 (1), 157-171

2 Fadllan, 2014, Obligasi Syariah; Antara Konsep Dan Implementasinya, Iqtisadhia, 1(2), h. 164
} 
dari instrumen tersebut masuk ke dalam ortofolio investasi reksadana. ${ }^{3}$ Pengembangan institusi termasuk pengembangan terhadap instrumen produk obligasi semakin bermunculan dengan sangat variatif. Sehingga, diterbitkanlah produk yang disebut dengan Obligasi Daerah.

Obligasi berdasarkan Keputusan Ketua Badan Pengawas Pasar Modal Dan Lembaga Keuangan Nomor: Kep-692/Bl/2011 merupakan surat hutang jangka panjang yang diterbitkan perusahaan atau pemerintah dengan nilai nominal dan jangka waktu jatuh tempo tertentu. Disamping itu obligasi merupakan jenis investasi jangka panjang bagi investor namun bagi pemerintah selaku penerbit obligasi merupakan hutang yang wajib dikembalikan. Selanjutnya kewajiban untuk mengembalikan utang dimaksud menimbulkan ketidakpastian bagi investor jika memperhatikan ketentuan Pasal 49 Ayat (4) Undang-Undang Nomor 1 Tahun 2004 tentang Perbendaharaan Negara yang menentukan bahwa, Barang milik negara/daerah dilarang untuk diserahkan kepada pihak lain sebagai pembayaran atas tagihan kepada pemerintah pusat/daerah. Dengan demikian timbul permasalahan dalam menyelesaikan kewajiban oleh Pemerintah Daerah mengingatan larangan pengalihan aset daerah sebagaimana diatur dalam Undang-undang Perbendaharaan Negara.

\section{Metode Penelitian}

Guna memperoleh pemecahan masalah atau mendapatkan jawaban yang akurat atas pertanyaan sebagai pokok permasalahan penelitian ini, akan dilakukan kegiatan yang menggunakan penalaran normatif untuk dapat menguraikan dalil logika, dalil postulat-postulat dan proporsi-proporsi yang menjadi dasar dari setiap langkah dan proses yang lazim ditempuh dalam kegiatan penelitian.

Penelitian ini menggunakan pendekatan normatif dilakukan terhadap ketentuanketentuan yang berkaitan dengan perjanjian kerjasama penanaman modal sebagai bahan utama untuk mengungkap permasalahan yang diteliti sedangkan pendekatan empirik digunakan sebagai penunjang kajian normatif terkait pengaturan penerbitan obligasi oleh pemerintah dan perlindungan hukum terhadap investor dalam transaksi obligasi oleh pemerintah.

Pendekatan yang diterapkan dalam penelitian tesis ini adalah jenis pendekatan Perundang-undangan (statute aproach) dan pendekatan Analisis Konsep Hukum (analitical and conceptual aproach). Pendekatan perundang-undangan adalah pendekatan dengan menggunakan legislasi dan regulasi sebagai obyek penelitian. Sedangkan pendekatan konseptual adalah pendekatan yang dilakukan manakala tidak beranjak dari aturan hukum yang ada, karena memang belum ditentukan secara jelas dalam peraturan perundang-undangan, oleh karena itu dibangun suatu konsep untuk dijadikan acuan didalam penelitian.

\footnotetext{
${ }^{3}$ Budiawan, C. N., Gunadi, 2013, Evaluasi Kebijakan Pajak Penghasilan Atas Bunga Obligasi Pada Industri Reksa Dana di Indonesia, Naskah Ringkas, Fakultas Ilmu Sosial dan Politik, Universitas Indonesia, h. 2 http:// www.lib.ui.ac.id/naskahringkas/2015-09/S47558-

Candra\%20Nur\%20Budiawan diakses, 30 Oktober 2018
} 
Dipergunakannya pendekatan-pendekatan tersebut dalam penelitian ini mengingat adanya konflik norma dalam pengaturan penerbitan obligasi oleh pemerintah dan perlindungan hukum terhadap investor dalam transaksi obligasi oleh pemerintah.

Bahan hukum yang diperoleh dikategorikan (dikelompokkan) dan secara sistematis, kemudian dianalisis dengan teknik mengabstraksikan peraturan perundang-undangan yang ada agar dapat menemukan asas-asas hukum yang terkandung dalam setiap Undang-undang, peraturan pernerintah dan peraturan-peraturan lainnya mengenai transaksi obligasi oleh permerintah melalui berbagai metode interpretasi. Dalam penelitian ini interpretasi yang digunakan ialah Gramatikal, Sistematis dan dalam melakukan analisis dibantu metode berpikir teoritik realistis deduktif (analisis deduktif)

\section{Hasil Dan Pembahasan}

\subsection{Konstruksi Pengaturan Obligasi Daerah}

Guna menentukan validitas norma yang mengatur tentang obligasi daerah maka dapat dikonstruksikan pengaturan Obligasi Daerah sebagai berikut:

a. Undang-undang Nomor 8 Tahun 1995 tentang Pasar Modal. Ketentuan undangundang ini mengatur salah satunya tentang obligasi.

b. Undang-undang Nomor 17 Tahun 2003 tentang Keuangan Negara.

c. Undang-undang Nomor 1 Tahun 2004 tentang Perbendaharaan Negara, dapat diketahui bahwa Obligasi Daerah dapat diterbitkan oleh pemerintah daerah sepanjang memenuhi persyaratan pinjaman.

d. Undang-undang Nomor 33 Tahun 2004 tentang Perimbangan Keuangan antara Pemerintah Pusat dan Pemerintah Daerah, yang pada intinya mengatur bahwa Pemerintah Daerah dapat menerbitkan obligasi daerah ${ }^{4}$

e. Peraturan Pemerintah Nomor 30 Tahun 2011 tentang Pinjaman Daerah.

f. Peraturan Menteri Keuangan Nomor 111/PMK.07/2012 tentang Tata Cara Penerbitan Pertanggungjawaban dan Obligasi Daerah.

\subsection{Perlindungan Hukum terhadap Investor dalam penerbitan Obligasi Daerah}

Penerbitan obligasi daerah oleh pemerintah daerah wajib mendapatkan persetujuan DPRD terlebih dahulu. Salah satu kewajiban tersebut seperti: kewajiban pembayaran bunga dan pokok yang timbul sebagai akibat penerbitan obligasi daerah pada saat jatuh tempo, mengingat ketentuan penerbitan obligasi oleh pemerintah daerah merupakan tindakan hukum publik yang berdapak pada perbuatan hukum keperdataan. Tindakan hukum pemerintah daerah dalam menerbitkan obligasi daerah merupakan tindakan hukum privat, karena tindakan tersebut terlibat dalam tindakan keperdataan. Tindakan hukum privat dimaksud adalah tindakan pemerintah dalam kedudukannya bukan sebagai pemerintah maupun bukan sebagai wakil dari badan dan bukan tugas untuk kepentingan umum sehingga tibdakannya berdasarkan pada ketentuan hukum privat (keperdataan).

\footnotetext{
${ }^{4}$ Pasal 57 Undang-Undang No. 33 Tahun 2004 Tentang Perimbangan Keuangan antara Pemerintah Pusat dan Pemerintah Daerah
} 
Tindakan hukum pemerintah adalah tindakan yang dilakukan oleh organ pemerintahan atau administrasi negara yang memiliki tujuan untuk menimbulkan akibat hukum dibidang pemerintahan. Berdasarkan konsep tersebut, tampak ada beberapa unsur-unsur dari tindakan hukum pemerintah dalam rangka penertiban obligasi daerah, yaitu: ${ }^{5}$

1. Perbuatan penerbitan obligasi daerah dilakukan oleh pemerintah daerah dalam kedudukannya sebagai alat perlengkapan pemerintahan dengan prakarsa dan tanggung jawab sendiri;

2. Perbuatan penerbitan obligasi menjalankan fungsi pemerintahan dalam rangka memperoleh pembiayaan bagi daerah;

3. Perbuatan menerbitkan obligasi daerah dapat menimbulkan akibat hukum dibidang administrasi berupa hak dan kewajiban;

4. Perbuatan menerbitkan obligasi daerah dimaksudkan demi kepentingan negara dan masyarakat;

5. Perbuatan menerbitkan obligasi daerah tersebut berdasarkan kepentingan peraturan perundang-undangan yang berlaku;

6. Perbuatan menerbitkan obligasi daerah berorientasi pada tujuan untuk memperoleh sumber lain pembiayaan daerah yang berlandaskan pada hukum.

Dengan demikian tindakan hukum pemerintah daerah dalam menerbitkan obligasi daerah merupakan tindakan hukum publik bersegi dua dan sekaligus juga merupakan tindakan hukum pemerintah daerah dalam bidang hukum privat oleh karena pada saat penerbitan obligasi daerah mengenai prosedur dan tatacaranya tunduk pada ketentuan-ketentuan dalam bidang pasar modal karena Pasar Modal (bursa efek) yang memiliki kewenangan memasarkan obligasi menurut Undang-undang Nomor 8 tahun 1995 tentang Pasar Modal, namun demikian tindakan penerbitan obligasi daerah berdasarkan ketentuan Undang-undang Nomor 17 Tahun 2003 dan Peraturan Pemerintah Nomor 30 Tahun 2011 tentang Pinjaman Daerah. Dalam hal demikian mengingat persyarat-persyaratan yang ditentukan maka tindakan pemerintah daerah dapat dikatagorikan sebagai tindakan pemerintah dalam bidang hukum publik.

Menurut Philipus M. Hadjon perlindunga hukum bagi rakyat terdapat dua bentuk yaitu perlindungan hukum preventif dan perlindungan hukum represif. ${ }^{6}$ Perlindungan hukum menurut Jimmly Asshidiqie, mengacu pada hukum tertulis dan hukum tidak tertulis dengan harapan ada jaminan terhadap benda yang dimiliki dalam menjalankan hak dan kewajiban. ${ }^{7}$

Pembayaran kembali terhadap obligasi yang telah dikeluarkan oleh pemerintah daerah adalah sebagai berikut: Pemerintah Daerah wajib membayar pokok dan bunga Obligasi Daerah pada saat jatuh tempo; dalam hal terdapat denda keterlambatan pembayaran pokok dan bunga, Pemerintah Daerah wajib membayar denda; pembayaran sebagaimana dimaksud dapat dianggarkan dalam APBD setiap tahun sampai dengan berakhirnya kewajiban tersebut, pembayaran kewajiban yang

\footnotetext{
5 Sadjijono, 2011, Bab-Bab Pokok Hukum Administrasi, Laksbang Pressindo, Yogyakarta, h.86

${ }^{6}$ Philipus M. Hadjon, 2007, Perlindungan Hukum Bagi Rakyat Indonesia, Percetakan M2 print, Surabaya,h.2

7 Jimmly Asshidiqie, 2000, Pergeseran-pergeseran Kekuasaan Legislatif dan Eksekutif, Universitas Indonesia, Jakarta,h. 97
} 
bersumber dari pendapatan daerah yang berasal dari penerimaan kegiatan yang dibiayai dengan Obligasi Daerah, dalam hal kegiatan belum menghasilkan dana yang cukup untuk membayar pokok, bunga, dan denda Obligasi Daerah, kewajiban pembayaran dibayarkan dari pendapatan daerah lainnya, dalam hal kewajiban pembayaran bunga Obligasi Daerah yang telah jatuh tempo melebihi dana yang dianggarkan, gubernur, bupati, atau walikota tetap melakukan pembayaran sebesar jumlah kewajiban yang telah jatuh tempo tersebut, realisasi kewajiban pembayaran bunga Obligasi Daerah sebagaimana dimaksud dianggarkan dalam perubahan APBD dan/atau dicantumkan dalam laporan realisasi anggaran.

Perlindungan hukum terhadap masyarakat sebagai investor obligasi daerah dapat diklasifikasikan dalam dua bentuk, yaitu:

1. Perlindungan Hukum Preventif diberikan dengan tujuan untuk mencegah terjadinya pelanggaran. Dengan mengatur secara konkrit mengenai obligasi daerah baik berupa undang-undang hingga Peraturan Daerah yang menegaskan mengenai hak dan kewajiban pemerintah serta investor dalam transaksi obligasi daerah.

2. Perlindungan Hukum Represif merupakan perlindungan hukum terhadap masyarakat dalam hal ini investor apabila terjadi permasalahan-permasalahan hukum antara pemerintah dengan investor melalui penegakan hukum dari peraturan perundang-undangan yang sudah diterbitkan sebagai bentuk perlindungan preventif. Mengingat adanya konflik norma dalam pengaturan obligasi daerah maka berdasarkan asas preferensi, yaitu " Lex Specialis Derogat Lex Generali" maka peraturan perundang-undangan khusus mengalahkan peraturan perundang-undangan yang bersifat umum. Dengan demikian penegakan hukum untuk memberikan perlindungan hukum terhadap investor obligasi daerah, dapat diterapkan tuntutan ganti kerugian dan kewajiban pemerintah untuk membayar kembali obligasi yang diterbitkan dapat dipergunakan ketentuan-ketentuan khusus yang mengatur tentang obligasi.

\subsection{Harmonisasi Pengaturan Obligasi Daerah dalam Perspektif Keuangan Daerah}

Prinsip-prinsip hukum yang yang adil mencakup harmonisasi antara maksud dan tujuan serta kepentingan perorangan, dan maksud dan tujuan serta kepentingan umum, yang terdiri atas dua unsur yaitu saling menghormati dan partisipasi demikian disampaikan oleh Rudolf Stammler, "A just law aim at harmonizing individual purpose with that of society." 8 Secara konseptual harmonisasi sistem hukum dapat dilakukan secara keseluruhan yang akan melibatkan mata rantai hubungan tiga komponen sistem hukum, yaitu substansi hukum (legal substance), struktur hukum beserta kelembagaannya (legal structure) dan kultur hukum (legal culture). ${ }^{9}$ Dengan demikian harmonisasi hukum adalah upaya atau proses untuk mengatasi batasan-batasan perbedaan, hal-hal yang bertentangan dan kejanggalan- kejanggalan dalam hukum, sehingga norma-norma hukum di dalam peraturan perundang-undangan sebagai subsistem dalam satu kesatuan kerangka sistem hukum tidak terhalang oleh

\footnotetext{
${ }^{8}$ Kusnu Goesniadhie, 2010, Harmonisasi Sistem Hukum Mewujudkan Tata Pemerintahan Yang Baik, Nasa Media, Malang, h.2

${ }^{9}$ Ibid h.6
} 
perbedaan-perbedaan, tidak saling bertentangan dan tidak saling duplikasi atau tumpang tindih. ${ }^{10}$

Dalam kaitannya dengan penyelarasan terhadap permasalahan inkonsistensi pengaturan penerbitan obligasi daerah, dapat diawali dengan penyelarasan dan penyerasian tujuan, strategi dan pedoman penerbitan obligasi daerah yaitu untuk membantu pembiayaan pemerintah daerah dalam membangun sarana dan prasarana fasilitas publik demi kepentingan masyarakat luas melalui penafsiran hukum, konstruksi hukum, penalaran dan pemberian argumentasi yang rasional dengan tetap memperhatikan sistem hukum dan asas-asas hukum.

adapun langkah-langkah yang dapat dilakukan dalam rangka harmonisasi pengaturan penerbitan obligasi daerah adalah sebagai berikut:

a. Identifikasi letak ketidakharmonisan dari ketentuan Undang-undang No.1 Tahun 2004 tentang Perbendaharaan Negara dengan Peraturan Pemerintah No. 58 Tahun 2005 tentang Pengelolaan Keuangan Daerah, mengenai tanggungjawan pmerintah daerah terhadap investor dalam rangka penerbitan obligasi daerah.

b. Penyebab terjadinya disharmonisasi adalah validitas norma yang terdapat pada peraturan yang lebih rendah terhadap peraturan yang lebih tinggi .

c. Upaya penemuan hukum dengan menggunakan metode penafsiran dan konstruksi hukum dilakukan merujuk pada ketentuan hukum keperdataan khususnya hukum perjanjian, dimana apabila telah terjadi kesepakatan kontraktual antara pemerintah dengan investor obligasi, maka kewajiban pemerintah untuk menyelesaikan kesepakatan tidak dapat dikesampingkan.

Dengan demikian perbuatan hukum penerbitan obligasi daerah oleh pemerintah daerah merupakan hubungan hukum keperdataan yang berlandaskan pada ketentuan hukum publik sebagai dasar kewenangan pemerintah dalam menerbitkan obligasi daerah.

\section{Kesimpulan}

Berdasarkan uraian pembahasan tersebut diatas maka dapat dikemukakan bahwa konstruksi normatif pengaturan obligasi daerah terdiri dari peraturan perundangundangan yang bersifat umum dan pengaturan yang bersifat khusus. Konstruksi pengaturan umum berisi kaedah sebagai ketentuan-ketentuan yang memberikan dasar legalitas penertiban obligasi daerah, sementara itu norma pengaturan obligasi daerah yang bersifat khusus yang berisikan kaedah-kaedah teknis penerbitan obligasi berupa ketentuan mengenai persyaratan dan prosedur. Perlindungan hukum terhadap investor obligasi daerah, penegakan hukumnya dapat diterapkan dalam hal tuntutan ganti kerugian dan kewajiban pemerintah untuk membayar kembali obligasi yang diterbitkan dapat dipergunakan ketentua-ketentuan khusus yang mengatur tentang obligasi.

${ }^{10}$ Ibid,h.9 


\section{Ucapan terima Kasih (Acknowledgments)}

Terimakasih disampaikan kepada Rektor cq Ketua LPPM Universitas Udayana yang telah memberikan pembiayaan dalam melakukan penelitian terkait topik penulisan ini; kepada Dekan Fakultas Hukum yang telah memfasilitasi penyusunan artikel ini dan semua pihak yang tidak dapat disebutkan satu persatu yang telah berkontribusi hingga selesainya artikel ini.

\section{Daftar Pustaka}

Buku

Azheri, B. (2012). Corporate Social Responsibility Dari Voluntary Menjadi Mandatory. Jakarta: PT Raja Grafindo Persada.

Sulistyastuti, D. R. 2002. Saham dan Obligasi, Ringkasan Teori dan Soal Jawab, Universitas Atmajaya, Yogyakarta, h. 82

Sadjijono, 2011. Bab-Bab Pokok Hukum Administrasi, Laksbang Pressindo, Yogyakarta.

Hadjon, P. M. 2007. Perlindungan Hukum Bagi Rakyat Indonesia, Percetakan M2 print, Surabaya.

Asshidiqie, J. 2000. Pergeseran-pergeseran Kekuasaan Legislatif dan Eksekutif, Universitas Indonesia, Jakarta.

Goesniadhie, K. 2010. Harmonisasi Sistem Hukum Mewujudkan Tata Pemerintahan Yang Baik, Nasa Media, Malang.

\section{Jurnal}

Fadllan, 2014, Obligasi Syariah; Antara Konsep Dan Implementasinya, Iqtisadhia, 1(2), 163-175

Okta, D., Kluge, D., 2011, Analisis Peluang Penerbitan Obligasi Daerah Sebagai Alternatif Pembiayaan Daerah, Journal of Indonesian Applied Economics, 5 (1), 157171

\section{Peraturan Perundang-undangan}

Undang-undang Nomor 8 Tahun 1995 tentang Pasar Modal

Undang-undang Nomor 17 Tahun 2003 tentang Keuangan Negara

Undang-undang Nomor 1 Tahun 2004 tentang Perbendaharaan Negara

Undang-undang Nomor 33 Tahun 2004 tentang Perimbangan Keuangan antara

Pemerintah Pusat dan Pemerintah Daerah

Peraturan Pemerintah Nomor 58 Tahun 2005 tentang Pengelolaan Keuangan Daerah

Peraturan Pemerintah Nomor 30 Tahun 2011 tentang Pinjaman Daerah

Peraturan Menteri Keuangan Nomor 111/PMK.07/2012 tentang Tata Cara Penerbitan Pertanggungjawaban dan Obligasi Daerah

Keputusan Ketua Badan Pengawas Pasar Modal Dan Lembaga Keuangan Nomor: Kep692/Bl/2011 Tentang Pedoman Mengenai Bentuk Dan Isi Pernyataan Pendaftaran Dalam Rangka Penawaran Umum Obligasi Daerah 


\section{Internet}

Budiawan, C. N., Gunadi, 2013, Evaluasi Kebijakan Pajak Penghasilan Atas Bunga Obligasi Pada Industri Reksa Dana di Indonesia, Naskah Ringkas, Fakultas Ilmu
Sosial dan
Politik,
Universitas
Indonesia,
h.

http://www.lib.ui.ac.id/naskahringkas/2015-09/S47558-

Candra\%20Nur\%20Budiawan diakses, 30 Oktober 2018 